\title{
Influence of temperature in pollution-induced community tolerance approaches used to assess effects of copper on freshwater phototrophic periphyton
}

\author{
Anne Sophie Lambert ${ }^{1}$; Aymeric Dabrin ${ }^{1}$; Arnaud Foulquier $^{2}$; Soizic Morin ${ }^{3}$; Christophe \\ Rosy $^{1}$; Marina Coquery ${ }^{1}$; Stéphane Pesce ${ }^{1}$ \\ ${ }^{1}$ Irstea, UR MALY, centre de Lyon-Villeurbanne, 5 rue de la Doua, BP 32108, 69616 Villeurbanne \\ Cedex, France. \\ ${ }^{2}$ Laboratoire d'Écologie Alpine - UMR CNRS 5553, Université Grenoble Alpes, BP 53, 38041 \\ Grenoble Cedex 9, France. \\ ${ }^{3}$ Irstea, UR EABX, 50 avenue de Verdun, 33612 Cestas, France.
}

\section{Corresponding author:}

Stéphane Pesce: Irstea, UR MALY, centre de Lyon-Villeurbanne, 5 rue de la Doua, BP 32108, 69616 Villeurbanne Cedex, France

stephane.pesce@irstea.fr

\section{Other e-mail addresses:}

annesophielambert@orange.fr

aymeric.dabrin@irstea.fr

arnaud.foulquier@univ-grenoble-alpes.fr

soizic.morin@irstea.fr

christophe.rosy@irstea.fr

marina.coquery@irstea.fr

\begin{abstract}
By measuring levels of tolerance to toxicants in microbial communities using functional toxicity tests under controlled conditions, pollution-induced community tolerance (PICT) approaches offer an effect-based tool to assess the ecological risk of chemicals in aquatic systems. However, induced tolerance of exposed microbial communities cannot always be attributed solely to the presence of toxicants as various environmental factors, such as temperature, can also be involved. Several PICT studies have been conducted to assess the effects of copper $(\mathrm{Cu})$ on phototrophic periphyton, but little is known about the influence of temperature on the response of these microbial communities to acute and chronic exposure to $\mathrm{Cu}$. Here, we report on a microcosm approach to assess the effects of two contrasting temperatures $\left(18{ }^{\circ} \mathrm{C}\right.$ and $\left.28{ }^{\circ} \mathrm{C}\right)$ on (i) the baseline level of $\mathrm{Cu}$ tolerance in non-Cuexposed phototrophic periphyton (i.e. effect of temperature on tolerance baseline), (ii) $\mathrm{Cu}$ tolerance acquisition by phototrophic periphyton in response to a 3-week chronic exposure to $\mathrm{Cu}$ at a nominal concentration of $60 \mu \mathrm{g} \mathrm{L}-1$ (i.e. effect of temperature on PICT selection) and (iii) tolerance measured during short-term toxicity tests (i.e. effect of temperature on PICT detection). The aim was to evaluate how temperature conditions during the different phases of the PICT approaches may modify the causal relationship between chronic $\mathrm{Cu}$ exposure and measured $\mathrm{Cu}$ tolerance levels. Our results evidence the influence of temperature both on the basal capacity of phototrophic periphyton to tolerate subsequent exposure to $\mathrm{Cu}$ (i.e. influence on tolerance baseline) and on its capacity to acquire tolerance following chronic exposure to $\mathrm{Cu}$ (i.e. influence on PICT selection). Hence temperature must be considered when using PICT to establish causal links between chronic $\mathrm{Cu}$ exposure and effects on phototrophic periphyton.
\end{abstract}




\section{Keywords:}

Biofilm; Metal; Microbial ecotoxicology; Combined stress; PICT; Short-term toxicity tests.

\section{Introduction}

Periphyton is a complex assemblage of phototrophic and heterotrophic microorganisms that can be a valuable indicator of toxic pollution in aquatic systems (Sabater et al., 2007). However, it is necessary to in situ distinguish toxicant effects from those due to other environmental variables. The pollutioninduced community tolerance (PICT) approach offers a way to isolate, at least partially, the effects of individual toxicants or classes of toxicants (according to their mode of action) within an ecosystem subjected to multiple stressors by studying shifts in community sensitivity (Schmitt-Jansen et al., 2008; Tlili et al., 2016). PICT assumes that chronic exposure of a biological community to toxicants can drive a species succession in which sensitive species are superseded by more tolerant ones (Blanck, 2002), and/or specific mechanisms of adaptation such as detoxification occur (Tlili and Montuelle, 2011). The resulting tolerance at community level can then be evaluated using short-term toxicity tests on selected microbial functions to determine effective concentrations (e.g. EC50) after acute exposure to the toxicant exerting the selection pressure (or a toxicant with a similar mode of action), using the dose-response toxicology model (Schmitt-Jansen et al., 2008).

Heavy metals, which are common contaminants of freshwaters, are potentially toxic for aquatic microbial communities (e.g. Gustavson and Wängberg, 1995; Fechner et al., 2010; Rotter et al., 2011). Copper $(\mathrm{Cu})$ is a widespread contaminant in rivers, especially those draining agricultural catchments, notably due to its use as a fungicide in both conventional and organic agriculture (Barón et al., 1995). Copper is an essential element for microorganisms. It serves as a cofactor in a number of enzymes that catalyze a wide variety of functions such as photosynthetic and mitochondrial electron transport or several redox reactions (Ladomersky and Petris, 2015; Adams et al., 2016). However, it is known since several decades that $\mathrm{Cu}$ can also exert toxic effects on microorganisms. Toxicity mechanisms of $\mathrm{Cu}$ notably involve the generation of reactive oxygen species (Okamoto et al., 2001; Sabatini et al., 2009). Toxic effects of $\mathrm{Cu}$ on phototrophic microorganisms also include lipid peroxidation (Rijstenbil et al., 1994) and increased membrane permeability (Cid et al., 1995), decrease in chlorophyll and accessory pigments content (Rijstenbil et al., 1994), and reduction in growth rates (Prasad et al., 1998). At community level, chronic exposure to $\mathrm{Cu}$ can functionally impair phototrophic microbial communities by reducing photosynthetic activity (Soldo and Behra, 2000; Lambert et al., 2012). It can also impact community structure via changes in the distribution of algal classes and the taxonomic composition of diatom communities (Morin et al., 2012; Serra and Guasch, 2009). These changes can ultimately increase phototrophic community tolerance to $\mathrm{Cu}$, in line with the PICT concept (Soldo and Behra, 2000; Tlili et al., 2010). In lotic ecosystems, tolerance levels of phototrophic periphyton communities to metals are generally assessed by measuring photosynthetic parameters (e.g. Dorigo et al., 2010; Foulquier et al., 2015).

Several recent case studies have demonstrated the potential of PICT approaches to help assess the ecological status of aquatic ecosystems (Larras et al., 2016; Pesce et al., 2016; Tlili et al., 2017). However, integrating PICT in monitoring programs still faces a number of challenges (Tlili et al., 2016) including (i) the need to define tolerance baselines which are the tolerance levels for communities which have not been previously exposed to a selected toxicant or other toxicants with the same mode of action, (Pesce et al., 2016), and (ii) the need to improve the distinction between effects of toxicants and confounding effects due to other environmental factors so as to obtain a better understanding of how communities respond to combined stress (Schmitt-Jansen et al., 2016). Both tolerance baseline and toxicant-induced tolerance can be modified by external factors, such as light 
(Guasch et al., 1998; Guasch and Sabater, 1998), nutrients (Tlili et al., 2010) or other toxicants favoring co-tolerance effects (Schmitt-Jansen et al., 2008), and by internal characteristics such as periphyton biomass (Guasch et al., 2003; Lambert et al., 2015) or community composition and species interactions (Guasch et al., 1998; Bérard et al., 1999).

Global warming and increasing frequency of extreme climate events (Easterling et al., 2000; Wreford and Adger, 2010) mean that freshwaters may increasingly undergo strong fluctuations in water temperature that can extend beyond normal seasonal and daily temperature variations (Smith, 2011). In lotic ecosystems, such variations in water temperature can impact periphyton, and thus potentially influence community tolerance to toxicants. Boivin et al. (2005) showed that periphytic bacterial communities growing at $14{ }^{\circ} \mathrm{C}$ and $20{ }^{\circ} \mathrm{C}$ under $\mathrm{Cu}$ exposure were respectively three and six times more Cu-tolerant than communities growing at $10{ }^{\circ} \mathrm{C}$. Larras et al. (2013) showed that spring lacustrine phototrophic periphyton growing at $18{ }^{\circ} \mathrm{C}$ was more sensitive to a herbicide mixture than that growing at higher temperatures (i.e. $21^{\circ} \mathrm{C}, 24^{\circ} \mathrm{C}$ and $28{ }^{\circ} \mathrm{C}$ ). Contrastingly, Morin et al. (2017) recently suggested a decrease in $\mathrm{Cu}$ tolerance of winter phototrophic periphyton with temperature (from $8{ }^{\circ} \mathrm{C}$ to $23{ }^{\circ} \mathrm{C}$ ), where higher temperatures decreased diatom species diversity and exacerbated community sensitivity towards $\mathrm{Cu}$. While being scarce, these earlier results suggest that temperature is an important environmental parameter to consider when interpreting results from PICT approaches seeking to establish firm causal links between chronic $\mathrm{Cu}$ exposure and effects on phototrophic periphyton.

Since little is known about the influence of temperature on the response of phototrophic periphytic communities to acute and chronic exposure to $\mathrm{Cu}$ (Lambert et al., 2016; Morin et al., 2017), the aim of this microcosm study (Fig. 1) was to assess the effects of two contrasting water temperatures $\left(18{ }^{\circ} \mathrm{C}\right.$ and $28{ }^{\circ} \mathrm{C}$ ) on (i) the baseline level of $\mathrm{Cu}$ tolerance in non-exposed phototrophic periphyton (i.e. effect of temperature on tolerance baseline), (ii) $\mathrm{Cu}$ tolerance acquisition by phototrophic periphyton in response to 3-week chronic exposure to $\mathrm{Cu}$ at a nominal concentration of $60 \mu \mathrm{g} \mathrm{L}-1$ (i.e. effect of temperature on PICT selection) and (iii) the resulting $\mathrm{Cu}$ tolerance levels measured after short-term toxicity test on photosynthetic efficiency (i.e. effect of temperature on PICT detection). Based on previous studies showing that a $10{ }^{\circ} \mathrm{C}$ temperature increase could significantly modify the community structure of phototrophic periphyton (Di Pippo et al., 2012; Larras et al., 2013; Lambert et al., 2016; Morin et al., 2017) and select diatom species exhibiting lower tolerance to $\mathrm{Cu}$ (Morin et al., 2017), we hypothesized that communities growing at $28^{\circ} \mathrm{C}$, with or without $\mathrm{Cu}$ exposure, would be less tolerant to subsequent acute exposure to $\mathrm{Cu}$ during PICT detection than communities growing at $18{ }^{\circ} \mathrm{C}$.

\section{Materials and Methods}

\subsection{Experimental set-up}

The microcosm experiment was carried out using 12 independent aquariums (glass, $40 \times 20 \times 25 \mathrm{~cm}$ ) incubated in two tanks (polyethylene, $250 \mathrm{~L}, 121 \times 81 \times 33 \mathrm{~cm}$ ) containing water thermoregulated at $18{ }^{\circ} \mathrm{C}$ (i.e. close to the average temperature measured in the field during the sampling period) and $28{ }^{\circ} \mathrm{C}$, respectively (Fig. 1). This high $28{ }^{\circ} \mathrm{C}$ temperature was chosen as a worst-case scenario, based on the temperatures recorded in the Morcille river, where the periphyton used in this study was sampled $\left(26.9^{\circ} \mathrm{C}\right.$ recorded at $6: 00 \mathrm{pm}$ on $21 / 07 / 2015$ in the downstream section of the Morcille river, unpublished data).

In each tank, six microcosms were filled with $16 \mathrm{~L}$ (i.e. $20 \mathrm{~cm}$ depth) of reconstituted water consisting of 3:1 (v/v) distilled water:groundwater supplemented with nutrients to adjust conductivity (i.e. about $180 \mu \mathrm{S} \mathrm{cm}-1$ ) and nutrient concentrations (i.e. $15 \mathrm{mg} \mathrm{L}-1$ silica; $8 \mathrm{mg} \mathrm{L}-1$ nitrates; $0.2 \mathrm{mg} \mathrm{L}-1$ phosphates) to the characteristics of the Morcille river (Dorigo et al., 2010) (Table 1). Each microcosm was fitted with a submerged pump (New Jet 800) to keep the water constantly mixed and oxygenated, 
and each tank was fitted with three submerged pumps to homogenize water temperature. Highpressure sodium lamps were used to deliver a constant light intensity of 3500 lx (42.7 $\mu \mathrm{mol} \mathrm{m-2} \mathrm{s-1)}$ under a $13 \mathrm{~h} / 11 \mathrm{~h}$ light/dark photoperiod, corresponding to the field conditions at the sampling date (May 19th, 2014). For each temperature condition (i.e. $18{ }^{\circ} \mathrm{C}$ and $28{ }^{\circ} \mathrm{C}$ ), three microcosms were used as control microcosms (without $\mathrm{Cu}$ addition), and three " $\mathrm{Cu}$ " microcosms were supplemented with $\mathrm{CuSO} 4 \cdot 5 \mathrm{H} 2 \mathrm{O}$ to obtain a $\mathrm{Cu}$ concentration close to $60 \mu \mathrm{g} \mathrm{L}-1$. This high $\mathrm{Cu}$ exposure level was chosen based on previous studies (e.g. Tlili et al., 2010; Lambert et al., 2012) in order to promote the selection of tolerant species and induce significant changes in community composition compared with the non-exposed control microcosms. To limit $\mathrm{Cu}$ adsorption by the experimental equipment during the exposure period, $\mathrm{Cu}$ microcosms (including glass slides and pumps) were contaminated using the same $\mathrm{Cu}$ concentration for $24 \mathrm{~h}$ before the start of the experiment. All the microcosms were filled with uncolonized artificial substrates (glass slides) to allow periphyton settlement during the experiment. Just before the experiment started, stones were collected at the reference upstream site of the Morcille river to retrieve periphyton (Beaujolais, Eastern France, see Montuelle et al. (2010) for details). The periphyton was scraped and suspended in river water to obtain a periphytic inoculum, which was homogenized, and then added in equal volumes to all the microcosms at the start of the experiment (Week 0).

The study lasted 5 weeks. During Week 1, the water level of each microcosm was adjusted, and each nutrient was added to maintain the initial trophic conditions. Water was then renewed weekly to maintain $\mathrm{Cu}$ exposure and avoid nutrient depletion. From Week 2 to Week 5, the main physical and chemical water parameters were measured in each aquarium before and $2 \mathrm{~h}$ after each water renewal. Conductivity, $\mathrm{pH}$, and dissolved oxygen concentrations were measured using portable meters (WTW, Germany). Water samples were collected at the same time for subsequent laboratory analyses.

Water temperature was recorded every hour with data loggers (HOBO® Pendant Temperature/Light, Prosensor). Water temperatures in the microcosms were close to the target temperatures, with mean values of $18.3{ }^{\circ} \mathrm{C}( \pm 0.5$; $\min 17.5, \max 19.9)$ and $27.0^{\circ} \mathrm{C}( \pm 1.8$; $\min 22.9, \max 29.4)$, respectively, with no significant difference between control and $\mathrm{Cu}$ microcosms.

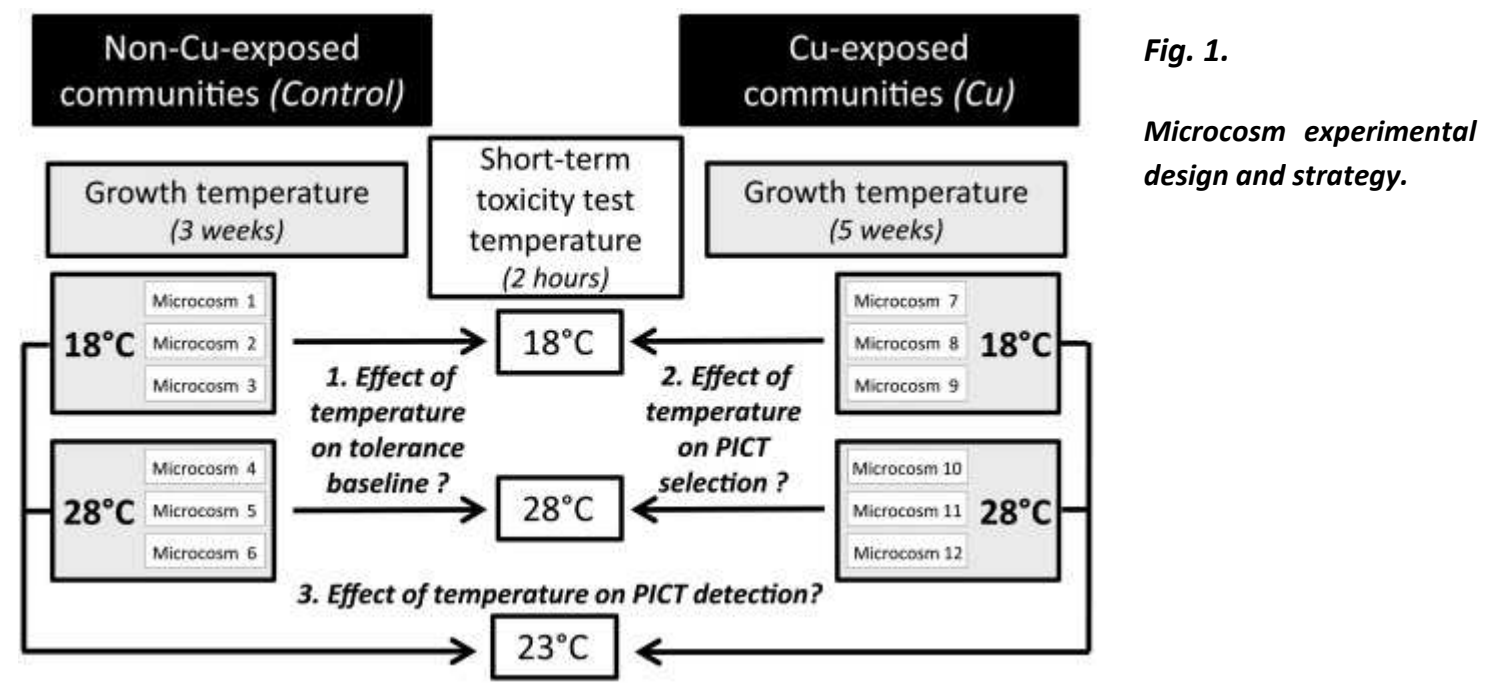

\subsection{Chemical analyses}

Standard operating procedures were followed to determine the concentrations of orthophosphates (PO4; NF EN ISO 6878), nitrates (NO3; NF EN ISO 10304), nitrites (NO2; NF EN 26777), ammonium (NH4; NF T 90-015-2), silica (SiO2; NF T 90-007) and dissolved organic carbon (DOC; NF EN 1484). 
To measure dissolved $\mathrm{Cu}$ concentrations, $30 \mathrm{~mL}$ of microcosm water was sampled before and after each water renewal, filtered $(0.45 \mu \mathrm{m}$ polyvinylidene difluoride (PVDF) filter, Whatman), acidified with $0.5 \%$ (v:v) nitric acid (Suprapur, Merck), and stored at $4{ }^{\circ} \mathrm{C}$ until analysis. Filtered water samples were analyzed using inductively coupled plasma - mass spectrometry (ICP-MS XSeries II, Thermo Electron). Quality controls were routinely checked using a certified reference material (Environment Canada, TM 27-3, Lake Ontario natural water) to check analytical accuracy (97\%) and precision ( \pm $12 \%)$.

In the control microcosms, dissolved $\mathrm{Cu}$ concentrations remained very low $(0.4 \pm 0.1 \mu \mathrm{g} \mathrm{L}-1)$ throughout the experiment. In all $\mathrm{Cu}$ microcosms, at $2 \mathrm{~h}$ after water renewal, mean dissolved $\mathrm{Cu}$ concentrations were $63.0 \pm 8.8 \mu \mathrm{g} \mathrm{L}-1$ with no significant difference among treatments. As previously observed in similar microcosm experiments (Lambert et al., 2012, 2016), Cu concentrations decreased strongly between each water renewal (from $43 \%$ to $60 \%$ according to the sampling time). Mean dissolved $\mathrm{Cu}$ concentrations before water renewal were $32.2 \pm 8.0 \mu \mathrm{g} \mathrm{L}-1$, with no significant difference among treatments.

\begin{tabular}{|c|c|c|c|c|c|}
\hline & \multirow{3}{*}{$\begin{array}{l}\text { Initial conditions (after water } \\
\text { renewal) } \\
\text { All microcosms }(n=12)\end{array}$} & \multicolumn{4}{|c|}{$\begin{array}{l}\text { Conditions after } 1 \text { week (before water } \\
\text { renewal) }\end{array}$} \\
\hline & & \multicolumn{2}{|c|}{ Control $(n=3)$} & \multicolumn{2}{|l|}{$\mathrm{Cu}(n=3)$} \\
\hline & & $18^{\circ} \mathrm{C}$ & $28^{\circ} \mathrm{C}$ & $18^{\circ} \mathrm{C}$ & $28^{\circ} \mathrm{C}$ \\
\hline $\mathrm{pH}$ & $8.7 \pm 0.4$ & $8.5 \pm 0.3$ & $8.8 \pm 0.2$ & $8.3 \pm 0.3$ & $8.5 \pm 0.5$ \\
\hline $\begin{array}{l}\text { Conductivity } \\
\left(\mu \mathrm{S} \mathrm{cm}^{-1}\right)\end{array}$ & $146 \pm 4$ & $132 \pm 13$ & $127 \pm 22$ & $148 \pm 4$ & $153 \pm 11$ \\
\hline $\mathrm{DO}\left(\mathrm{mg} \mathrm{L}^{-1}\right)$ & $8.64 \pm 0.62$ & $9.53 \pm 0.54$ & $8.68 \pm 0.37$ & $9.32 \pm 0.37$ & $8.11 \pm 0.69$ \\
\hline $\operatorname{DOC}\left(\mathrm{mg} \mathrm{L}^{-1}\right)$ & $<0.5$ & $1.01 \pm 0.41$ & $1.21 \pm 0.27$ & $0.60 \pm 0.10$ & $0.87 \pm 0.68$ \\
\hline $\mathrm{NO}_{3}\left(\mathrm{mg} \mathrm{L}^{-1}\right)$ & $6.43 \pm 0.53$ & $2.60 \pm 2.40$ & $2.40 \pm 2.10$ & $5.28 \pm 1.05$ & $5.41 \pm 1.54$ \\
\hline $\mathrm{NO}_{2}\left(\mathrm{mg} \mathrm{L}^{-1}\right)$ & $<0.02$ & $<0.02$ & $0.03 \pm 0.02$ & $0.02 \pm 0.01$ & $0.08 \pm 0.04$ \\
\hline $\mathrm{NH}_{4}\left(\mathrm{mg} \mathrm{L}^{-1}\right)$ & $<0.02$ & $<0.02$ & $<0.02$ & $0.03 \pm 0.01$ & $0.07 \pm 0.05$ \\
\hline $\mathrm{PO}_{4}\left(\mathrm{mg} \mathrm{L}^{-1}\right)$ & $0.20 \pm 0.04$ & $0.04 \pm 0.01$ & $<0.03$ & $0.10 \pm 0.06$ & $0.07 \pm 0.05$ \\
\hline $\mathrm{SiO}_{2}\left(\mathrm{mg} \mathrm{L}^{-1}\right)$ & $4.40 \pm 0.74$ & $1.10 \pm 1.06$ & $0.76 \pm 0.48$ & $4.40 \pm 1.01$ & $4.83 \pm 1.45$ \\
\hline
\end{tabular}

Table 1.

Physical-chemical characteristics of water in the control and $\mathrm{Cu}$ microcosms for the four tested conditions before (i.e. conditions after 1 week) and 2 h after each water renewal (i.e. initial conditions), for 5 weeks (means value \pm standard deviation [s.d.], $n=3$ ).

DO, dissolved oxygen; DOC, dissolved organic carbon.

\subsection{Periphyton characterization and tolerance assessment}

The biofilm growth cycle includes successive phases namely initial cell attachment to a surface, microcolony formation, biofilm maturation and detachment (also termed dispersal). Given the importance of the growth state on PICT measurement (Lambert et al., 2015), the sampling strategy used to collect periphyton in the microcosms was based on growth curve analysis to perform PICT analysis on biofilms collected during their advanced stage of maturation (and before cell detachment). Periphytic communities were collected at the end of the exponential growth (i.e. mature state) to assess the tolerance levels on mature assemblages while limiting the cell detachment process. In the control microcosms, algal biomass rapidly increased, and a mature periphyton was obtained within three weeks. By contrast, $\mathrm{Cu}$ induced a slower algal growth, and periphyton became mature only after 5 weeks. Accordingly, periphyton characterization and tolerance assessment were performed after 3 weeks of development for control communities (to limit cell detachment) and after 5 weeks of development for $\mathrm{Cu}$ communities. About 15 slides were randomly collected in each microcosm, and periphyton was carefully scraped off with a razor blade, suspended in 1:1 (v/v) demineralized:mineral water (Volvic, France), and homogenized to obtain one periphyton suspension per microcosm. Each suspension was divided up into different volumes to measure the following parameters. 
To measure algal cell density, $2 \mathrm{~mL}$ of periphyton suspension was immediately fixed in formalin (37\% formaldehyde, Prolabo, France) for counting. Each sample was counted using a Nageotte counting chamber (Marienfeld, Germany). After homogenization, $125 \mu \mathrm{L}$ of sample was placed in the counting chamber, and the total number of cells was recorded in 10 fields of the gridded area $(1.25 \mu \mathrm{L}$ each, 0.5 mm depth) under light microscopy at $\times 400$ magnification (Olympus BX51 upright microscope, UK). Microalgae were counted individually (i.e. enumeration of all cells when forming colonies) and discriminated, based on their morphological features, into diatoms, chlorophytes and cyanobacteria. For diatoms, dead and live organisms before fixation were distinguished by observation of the turgidity and color of the chloroplast, as described in Morin et al. (2010).

Aliquots of periphyton suspension ( $3 \mathrm{~mL}$ ) were also used to determine total chlorophyll a (chl a) and photosynthetic efficiency by multiwavelength pulse-amplitude-modulated (PAM) fluorimetry on a Phyto-PAM system (H. Walz, Germany) as described in Schmitt-Jansen and Altenburger (2008). Photosynthetic efficiency was based on measurement of the maximum PSII quantum yield (PSII) (Schmitt-Jansen and Altenburger, 2008), a measure of the physiological state of phototrophic communities (Tlili et al., 2010).

Photosynthetic efficiency was also used as endpoint to assess the tolerance of phototrophic periphyton communities to $\mathrm{Cu}$ in the PICT approach, following Lambert et al. (2015) with slight modifications. Given the influence of periphyton biomass on PICT measurement (Lambert et al., 2015), we diluted the initial periphyton suspension with an equivalent mixture of demineralized water and mineral water (Volvic, France) to obtain a periphyton suspension concentration of about $2000 \mu \mathrm{g}$ chl a L- 1 (as measured with the Phyto-PAM fluorimeter) for each sample before exposure of periphyton to increasing $\mathrm{Cu}$ concentrations.

A semi-logarithmic series of $\mathrm{Cu}$ concentrations was freshly prepared in the same 1:1 demineralized:mineral water mixture to obtain nine $\mathrm{Cu}$ concentrations, ranging from 0.32 to $3200 \mathrm{mg}$ $\mathrm{L}-1$. The $\mathrm{Cu}$ concentration of each solution was analyzed by ICP-MS as described above; $1.8 \mathrm{~mL}$ of the periphyton suspension was then exposed for $2 \mathrm{~h}$ to $0.9 \mathrm{~mL}$ of the different $\mathrm{Cu}$ solutions, to obtain final $\mathrm{Cu}$ concentrations ranging from 0.1 to $1000 \mathrm{mg} \mathrm{L}-1$.

The short-term $(2 \mathrm{~h})$ incubation was performed in climatic chambers (MLR-350 Versatile Environmental Test Chamber, Sanyo) under artificial light (1400 lx). To evaluate the influence of growth temperature on tolerance acquisition (i.e. during the PICT selection phase), the short-term incubation was carried out at the temperature of the microcosms during growth (i.e. $18{ }^{\circ} \mathrm{C}$ and $28{ }^{\circ} \mathrm{C}$, respectively) (Fig. 1). To assess the influence of incubation temperature on tolerance measurement (i.e. during the PICT-method detection phase), the short-term incubation was also carried out at the intermediate temperature between the two temperature conditions tested (i.e. $23^{\circ} \mathrm{C}$ ) (Fig. 1).

After $2 \mathrm{~h}$ incubation with the nine $\mathrm{Cu}$ solutions (three independent analytical replicates per replicate sample and per concentration) and the water blank (five independent analytical replicates per replicate sample), periphyton suspensions were kept for $30 \mathrm{~min}$ in a dark chamber, and maximum quantum yield of PSII was then measured on the Phyto-PAM (665 nm).

\subsection{Statistical analysis}

Variations in water and periphyton characteristics (physical and chemical characteristics, chl a, PSII yield, cellular density) between temperature conditions (during growth and toxicity tests) were tested by ANOVA followed by a post hoc Tukey test using R version 2.15.0 (R Development Core Team, 2012). Data were log-transformed before statistical analysis to satisfy the conditions of normality and homogeneity of variances. The analysis of results from short-term bioassays was conducted using functions from the 'drc' package (Ritz and Streibig, 2005) in R version 2.15.0 (R Development Core 
Team, 2012). For each microcosm, the dose-response curve was fitted to the data using the fourparameter log-logistic model given by the formula:

$$
\text { response }=c+\frac{d-c}{1+\exp \{b \times(\log (\text { Dose })-\log (e))\}},
$$

where $\mathrm{b}$ is slope of the curve around $\mathrm{e}, \mathrm{c}$ and $\mathrm{d}$ are the lower and upper limits of the curve, respectively, and e is EC50, the dose producing a response half-way between the upper and the lower limit of the curve. The response variable was expressed as the percentage of the yield of the uncontaminated control assay. EC50 was derived from each dose-response curve. ANOVAs followed by Tukey HSD tests were used to determine significant between-treatment differences in EC50, upper and lower limits, slope and percentage of inhibition.

\section{Results and discussion}

\subsection{Effect of temperature on tolerance baseline}

One limitation to the use of PICT in monitoring programs is the lack of knowledge about theoretical tolerance baselines that would preclude the need for reference samples in field studies (Pesce et al., 2016). The difficulty defining baseline values is due to spatial and seasonal variability in basal community tolerance related to the effects of various environmental factors, which cannot be controlled during in situ exposure and can act as confounding factors (Coulaud et al., 2011). To evaluate the potential influence of a drastic change in temperature on the baseline tolerance of phototrophic periphyton to $\mathrm{Cu}$, we assessed the effect of a $10{ }^{\circ} \mathrm{C}$ temperature rise on the $\mathrm{Cu}$ tolerance levels of non-Cu-exposed communities. The magnitude and range of the temperature increase were chosen as representative of extreme climatic events in the Morcille river where the periphyton used in this study was sampled (e.g. increase in water temperature from $18.3{ }^{\circ} \mathrm{C}$ to $25.8{ }^{\circ} \mathrm{C}$ between 21/06/2015 and 01/07/2015, unpublished data).

To avoid temperature stress during the measurement of baseline tolerance, toxicity tests were performed at growth temperature (i.e. $18{ }^{\circ} \mathrm{C}$ and $28{ }^{\circ} \mathrm{C}$ for periphyton growing at $18{ }^{\circ} \mathrm{C}$ and $28{ }^{\circ} \mathrm{C}$, respectively). After a growing period of three weeks at $18{ }^{\circ} \mathrm{C}$, which was representative of the river temperature during the initial sampling of periphyton, the basal tolerance of control phototrophic communities was characterized by an EC50 $\left(18^{\circ} \mathrm{C}\right.$ ) value for $\mathrm{Cu}$ of $2.58 \pm 0.31 \mathrm{mg} \mathrm{L}-1$ (Table 2). EC50 $\left(28^{\circ} \mathrm{C}\right)$ values obtained with non-Cu-exposed communities growing at $28{ }^{\circ} \mathrm{C}(0.71 \pm 0.41 \mathrm{mg}$ $\mathrm{L}-1$ ) were about three orders of magnitude lower than those obtained with $18{ }^{\circ} \mathrm{C}$ communities, revealing a notable decrease in their tolerance to $\mathrm{Cu}$ even if it was not statistically significant $(\mathrm{p}>$ 0.99). This result is consistent with the recent findings of Morin et al. (2017) who observed that warming (from $8{ }^{\circ} \mathrm{C}$ to $23{ }^{\circ} \mathrm{C}$ ) significantly decreased the basal tolerance of phototrophic biofilms towards acute exposure to $\mathrm{Cu}$. In their study, the change in basal tolerance was mainly attributable to a change in phototrophic community structure since temperature appeared to be an important driver for several diatom species (Morin et al., 2017) as previously shown (De Nicola, 1996; Larras et al., 2013). In the present study, the increase in the sensitivity to $\mathrm{Cu}$ at higher temperature in control phototrophic communities may stem, at least partially, from structural changes. In our experimental conditions, the $10{ }^{\circ} \mathrm{C}$ temperature increase was an important driver of phototrophic community evolution, where we found an increase in algal densities (Fig. 3), in particular in cyanobacteria, either solitary or forming short filaments. The observed decrease in basal tolerance may also have been due to physiological stress induced by the marked temperature increase, which could have weakened phototrophic communities, thus increasing their sensitivity to subsequent stress (i.e. $\mathrm{Cu}$ exposure during the toxicity test). This hypothesis is supported by the significant decrease observed in PSII values at $28{ }^{\circ} \mathrm{C}(\mathrm{p}=$ 
0.006; Fig. 2), which revealed an inhibitory effect of temperature on photosynthesis. The influence of temperature on periphyton photosynthesis has been sparsely researched, and results differ significantly among studies. For example, at variance with our results, Baulch et al. (2005) reported an increase in photosynthetic activity of periphyton when temperature increased by $4.5^{\circ} \mathrm{C}$ (with initial temperatures ranging between $9.3{ }^{\circ} \mathrm{C}$ and $14.3{ }^{\circ} \mathrm{C}$ ), whereas Larras et al. (2013) found that increasing the growing temperature from $18{ }^{\circ} \mathrm{C}$ to $28{ }^{\circ} \mathrm{C}$ had no effect on the maximum PSII quantum yields of lacustrine periphyton. This inconsistency among studies could be due to differences in initial taxonomic composition, and/or to differences in temperature gradients tested. It is well known that the thermal optimum for photosynthesis varies according to algal species (Necchi, 2004). In our case, the $10{ }^{\circ} \mathrm{C}$ temperature rise probably exceeded a temperature-mediated threshold for community tolerance.

\begin{tabular}{|c|c|c|c|c|c|c|c|c|}
\hline \multirow{3}{*}{$\begin{array}{l}\text { Growth temperature }\left({ }^{\circ} \mathrm{C}\right) \\
\text { Incubation temperature }\left({ }^{\circ} \mathrm{C}\right)\end{array}$} & \multicolumn{4}{|c|}{ Control } & \multicolumn{4}{|c|}{$\mathrm{Cu}$} \\
\hline & \multicolumn{2}{|c|}{18} & \multicolumn{2}{|c|}{28} & \multicolumn{2}{|c|}{18} & \multicolumn{2}{|c|}{28} \\
\hline & 18 & 23 & 28 & 23 & 18 & 23 & 28 & 23 \\
\hline$\overline{E C_{50}(m g / L)}$ & $2.58 \pm 0.31$ (a) & $2.01 \pm 0.41$ (a) & $0.71 \pm 0.41$ (a) & $1.35 \pm 0.68$ (a) & $44.82 \pm 14.13(\mathrm{a})$ & $40.02 \pm 2.32$ (a) & $1.41 \pm 0.14$ (b) & $1.76 \pm 0.90(b)$ \\
\hline Slope & $0.57 \pm 0.11$ (a) & $0.64 \pm 0.09$ (a) & $1.09 \pm 0.47$ (a) & $1.00 \pm 0.45$ (a) & $1.90 \pm 0.37$ (a) & $2.34 \pm 0.20$ (a) & $1.00 \pm 0.38 b)$ & $0.89 \pm 0.30(\mathrm{~b})$ \\
\hline Upper limit (yield; relative unit) & $0.52 \pm 0.01$ (a) & $0.56 \pm 0.02$ (a) & $0.46 \pm 0.02(a)$ & $0.45 \pm 0.07$ (a) & $0.53 \pm 0.01$ (a) & $0.52 \pm 0.01$ (a) & $0.32 \pm 0.03(b)$ & $0.28 \pm 0.07 b)$ \\
\hline Lower limit (yield; relative unit) & $0.00 \pm 0.00$ (a) & $0.00 \pm 0.00$ (a) & $0.00 \pm 0.00$ (a) & $0.03 \pm 0.05$ (a) & $0.19 \pm 0.06(a)$ & $0.15 \pm 0.04$ (a) & $0.01 \pm 0.01(b)$ & $0.00 \pm 0.01$ (b) \\
\hline PSII (\% of control) & $100 \pm 0$ (a) & $100 \pm 0$ (a) & $100 \pm 0$ (a) & $93 \pm 13$ (a) & $64 \pm 11$ (a) & $71 \pm 8$ (a) & $98 \pm 3(b)$ & $99 \pm 2$ (b) \\
\hline
\end{tabular}

Table 2. Tolerance measurements: summary of parameters derived from the dose-response curves obtained from short-term bioassays for control and Cu-exposed community microcosms. For a given parameter and a given $\mathrm{Cu}$ exposure context, different lower case letters indicate significant differences $(p<0.05)$ between temperature. Values are means \pm standard deviation for each microcosm $(n=3)$.

These results reveal that changes in temperature can notably modify the basal capacity of phototrophic periphyton to tolerate subsequent exposure to $\mathrm{Cu}$. This means that temperature is an important factor to consider when modeling the influence of environmental parameters to determine theoretical basal tolerance to metals. However, given the extreme temperature rise tested in the present work as well as the lack of statistical significance of the observed trend effect, further research is needed to make a more accurate assessment of how the basal tolerance can be influenced by more realistic temperature variations (e.g. seasonal and daily temperature variations or gradual increase following a prolonged heat event).

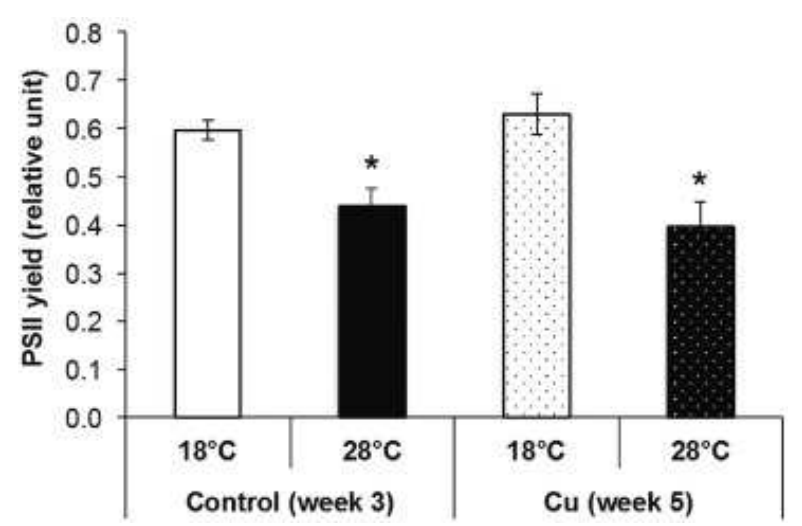

\subsection{Effect of temperature on PICT selection}

Fig. 2.

PSII yield (mean \pm s.d., in relative units; $n=3$ ) of control and Cu-exposed communities at week 3 and week 5 for growth temperatures $18{ }^{\circ} \mathrm{C}$ and $28{ }^{\circ} \mathrm{C}$. Asterisks indicate significant differences $(p<0.05)$ between $18{ }^{\circ} \mathrm{C}$ and $28{ }^{\circ} \mathrm{C}$ for each $\mathrm{Cu}$ treatment (control and $\mathrm{Cu}$ ).

The literature reports strong evidence that several-week exposure to $\mathrm{Cu}$ at environmental concentrations of some tens of $\mu \mathrm{g} \mathrm{L}-1$ (e.g. about $10 \mu \mathrm{g} \mathrm{L}-1$ in Tlili et al., 2011; about $25 \mu \mathrm{g} \mathrm{L}-1$ in Lambert et al., 2012) can induce structural changes in phototrophic periphytic communities, leading to an increase in their $\mathrm{Cu}$ tolerance (i.e. PICT selection). In our experiment, phototrophic communities were exposed to $\mathrm{Cu}$ concentrations between $24 \mu \mathrm{g} \mathrm{L}-1$ (i.e. lowest concentration recorded before water renewal) and $69 \mu \mathrm{g} \mathrm{L}-1$ (i.e. highest concentration recorded after water renewal). This exposure 
level remains environmentally relevant given that $\mathrm{Cu}$ concentrations can reach several hundred $\mu \mathrm{g} \mathrm{L}-$ 1 in highly contaminated rivers (e.g. Hirst et al., 2002; Cantonati et al., 2014). Unsurprisingly, phototrophic periphyton growing for 5 weeks at $18{ }^{\circ} \mathrm{C}$ with no heat stress treatment and under such $\mathrm{Cu}$ exposure exhibited high tolerance levels to $\mathrm{Cu}\left(\operatorname{EC} 50\left(18{ }^{\circ} \mathrm{C}\right)\right.$ of $44.8 \pm 14.1 \mathrm{mg} \mathrm{L}-1$; Table 2). The EC50 value was thus 17 times higher than that observed in control communities growing for 3 weeks at $18{ }^{\circ} \mathrm{C}(2.6 \pm 0.3 \mathrm{mg} \mathrm{L}-1)$. Despite the difference in growth duration between control and $\mathrm{Cu}-$ exposed communities, which prevents statistical comparison, this large difference evidenced an adaptation of phototrophic periphyton to $\mathrm{Cu}$ following chronic exposure. This result is in accordance with Soldo and Behra (2000), who reported a 6-fold increase in tolerance of phototrophic periphyton communities (based on EC50 values using photosynthesis rates measured by the $14 \mathrm{C}$ technique) after 12 weeks of exposure to $\mathrm{Cu}$ at $63.5 \mu \mathrm{g} \mathrm{L}-1$ (nominal concentration). To assess the effect of temperature on PICT selection, phototrophic periphytic communities were simultaneously exposed to $\mathrm{Cu}$ and subjected to a $10{ }^{\circ} \mathrm{C}$ increase. The EC50 $\left(28^{\circ} \mathrm{C}\right)$ of $\mathrm{Cu}$-exposed communities at $28{ }^{\circ} \mathrm{C}$ was over 30 times lower $(1.41 \pm 0.14 \mathrm{mg} \mathrm{L}-1)$ than the EC50 $\left(18{ }^{\circ} \mathrm{C}\right)$ of $\mathrm{Cu}$-exposed communities at $18{ }^{\circ} \mathrm{C}$ (44.8 $\pm 14.1 \mathrm{mg} \mathrm{L}-1$; Table 2), highlighting that the $10{ }^{\circ} \mathrm{C}$ increase in temperature led to a sharp, significant decrease in tolerance levels of $\mathrm{Cu}$ communities $(\mathrm{p}<0.001)$. Furthermore, the lower limit observed in the dose-response curves showed that PSII yield was almost completely inhibited (i.e. 98\%) when $\mathrm{Cu}$-exposed communities growing at $28{ }^{\circ} \mathrm{C}$ were exposed to the highest $\mathrm{Cu}$ concentration tested (3200 mg L- 1) in bioassays, whereas the PSII yield of $\mathrm{Cu}$-exposed communities growing at $18{ }^{\circ} \mathrm{C}$ was only reduced by about $64 \%(\mathrm{p}<0.001$; Table 2 ). Moreover, the upper limit revealed that basal PSII yield of $\mathrm{Cu}$-exposed communities was lower at $28{ }^{\circ} \mathrm{C}(0.32 \pm 0.03)$ than at $18{ }^{\circ} \mathrm{C}(0.53 \pm$ $0.01 ; \mathrm{p}<0.001)$. The same significant decrease in PSII yield between $18{ }^{\circ} \mathrm{C}$ - and $28{ }^{\circ} \mathrm{C}$-Cu-exposed communities was also observed when the measurement was made immediately after periphyton sampling in the microcosms $(\mathrm{p}<0.001$; Fig. 2). This strong decrease in PSII yield revealed a significant effect of the temperature increase on the physiological state of the chronically $\mathrm{Cu}$-exposed phototrophic communities. This effect could have weakened the $\mathrm{Cu}$-exposed communities growing at $28{ }^{\circ} \mathrm{C}$, decreasing their capacity to tolerate a subsequent acute exposure to copper, as suggested by the EC50 values. As mentioned above for non-exposed communities, changes in phototrophic community composition may also explain the increased vulnerability of periphyton towards acute exposure to $\mathrm{Cu}$ (Morin et al., 2017). With long-term $\mathrm{Cu}$ exposure, diatoms were almost eliminated from the community: at $18{ }^{\circ} \mathrm{C}$; diatoms only accounted for about $0.01 \%$ of the communities (Fig. 3), with a mortality of $15.7 \pm 9.7 \%$. This suggests that green algae and cyanobacteria were more $\mathrm{Cu}$-tolerant. However, the $10{ }^{\circ} \mathrm{C}$ increase in temperature led to changes in the growth forms of both green algae and cyanobacteria. At $18{ }^{\circ} \mathrm{C}$, soft algae in Cu-exposed communities were mostly solitary, or formed short 3-5 cell fragments, whereas the higher temperatures favored long filamentous colonies. The more heterogeneous algal community growing at $18{ }^{\circ} \mathrm{C}$, mostly composed of solitary cells with probably different sensitivity levels to $\mathrm{Cu}$, could explain the higher tolerance to low $\mathrm{Cu}$ concentrations, and the sharp decrease in PSII yield around the EC50, as shown by the significantly higher slope (Table 2$)$ at $18{ }^{\circ} \mathrm{C}(1.90 \pm 0.37)$ than at $28^{\circ} \mathrm{C}(1.00 \pm 0.38)(\mathrm{p}=0.022)$.

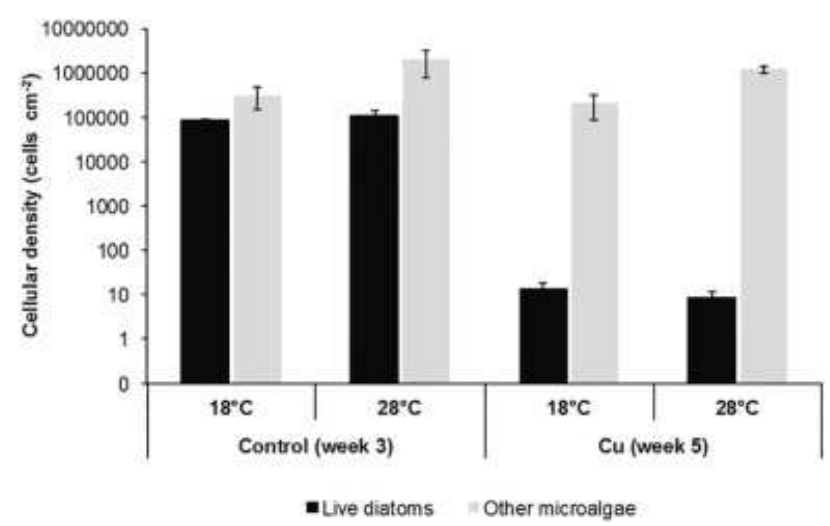

Fig. 3.

Cellular density (mean \pm s.d.; cells $\mathrm{cm}-2 ; n=3$ ) of live diatoms and other microalgae in control and Cu-exposed communities at week 3 and week 5 for growth temperatures $18{ }^{\circ} \mathrm{C}$ and $28^{\circ} \mathrm{C}$. Lack of asterisk indicates no significant differences $(p<0.05)$ between $18{ }^{\circ} \mathrm{C}$ and $28{ }^{\circ} \mathrm{C}$ for each treatment (control and $\mathrm{Cu}$ ) and each kind of biological parameter (Live diatoms and Other microalgae). 
These results thus suggest that in our experimental conditions, temperature and metal stress acted antagonistically on community tolerance acquisition, with a reduced tolerance to copper of the $\mathrm{Cu}$ exposed communities grown at $28{ }^{\circ} \mathrm{C}$. These findings are consistent with our initial hypothesis which was based on the results of Morin et al. (2017), who found that a temperature gradient increase from $8{ }^{\circ} \mathrm{C}$ to $23{ }^{\circ} \mathrm{C}$ selected for less Cu-tolerant diatom species, leading to a decrease in $\mathrm{Cu}$-induced community tolerance. Assessing in laboratory conditions the effects of $\mathrm{Cu}$ on the structure of mature biofilms collected in Dutch rivers, Barranguet et al. (2002, 2003) observed that phototrophic communities collected in summer (at a water temperature of $19.5^{\circ} \mathrm{C}$ ) were more strongly impacted by $\mathrm{Cu}$ than communities collected in spring $\left(11.5^{\circ} \mathrm{C}\right)$ exposed mature biofilms collected in Dutch rivers to copper in laboratory conditions. Their work showed that water temperature may lead to contrasting responses of diatoms to $\mathrm{Cu}$ exposure. Performing a 6-year in situ study in a river contaminated by cadmium and zinc, Morin et al. (2015) demonstrated that the effects of metal pollution on diatom diversity were more drastic during the hottest summers. Altogether, present and previous results evidence the influence of temperature on the acquisition of tolerance of phototrophic periphytic communities to $\mathrm{Cu}$ and other metals. That means that temperature is an important factor to consider when using PICT to establish causal links between chronic $\mathrm{Cu}$ exposure and effects on phototrophic periphyton.

\subsection{Effect of temperature on PICT detection}

Besides the influence of growth temperature on tolerance baseline and PICT selection, we also evaluated the influence of incubation temperature on tolerance measured during short-term toxicity tests, both for determining tolerance baseline (non-Cu exposed communities) and for assessing induced tolerance ( $\mathrm{Cu}$ exposed communities). To this end, phototrophic periphyton communities were incubated for $2 \mathrm{~h}$ with increasing concentrations of $\mathrm{Cu}$ at their respective growth temperatures $\left(18{ }^{\circ} \mathrm{C}\right.$ or $\left.28^{\circ} \mathrm{C}\right)$ and at an intermediate temperature $\left(23^{\circ} \mathrm{C}\right)$ (Fig. 1).

Short-term toxicity tests performed at $18{ }^{\circ} \mathrm{C}$ and $23{ }^{\circ} \mathrm{C}$ for control and $\mathrm{Cu}$-exposed communities growing at $18{ }^{\circ} \mathrm{C}$ found similar upper limits (i.e. yields of uncontaminated control assay; $\mathrm{C} 0$ ) irrespective of incubation temperature ( $p>0.75$ for control and $\mathrm{p}>0.99$ for $\mathrm{Cu}$; Table 2), suggesting a lack of any direct effect of short-term incubation temperature on photosynthetic efficiency. Moreover, incubation temperature had no effect ( $\mathrm{p}$ between 0.64 and 1.00) on the lower limit and slope of the dose-response curves (Fig. 4, Table 2). Furthermore, there was no significant difference between EC50 values obtained via short-term toxicity tests at $18{ }^{\circ} \mathrm{C}$ or $23{ }^{\circ} \mathrm{C}$ for either controls (about $2 \mathrm{mg} \mathrm{L}-$ $1, \mathrm{p}>0.99$ ) or Cu-exposed communities (about $40 \mathrm{mg} \mathrm{L}-1, \mathrm{p}>0.93$ ). Likewise, at a growth temperature of $28{ }^{\circ} \mathrm{C}$, there was no significant difference between EC50 values obtained from shortterm toxicity tests at $28{ }^{\circ} \mathrm{C}$ and $23{ }^{\circ} \mathrm{C}$ for either controls (about $1 \mathrm{mg} \mathrm{L}-1, \mathrm{p}>0.99$ ) or Cu-exposed communities (about $1.5 \mathrm{mg} \mathrm{L}-1, \mathrm{p}=1.00$ ). This study thus demonstrated that a $5{ }^{\circ} \mathrm{C}$ variation in incubation temperature applied during short-term toxicity tests had no significant influence on measured tolerance, regardless of the growth temperature and $\mathrm{Cu}$ exposure history.

Our investigation on the influence of thermal conditions on PICT measurement addresses the challenge of improving the standardization of PICT approaches for integration into regulatory frameworks for assessing ecological and chemical status of aquatic ecosystems (Pesce et al., 2016; Tlili et al., 2016). In our experimental context, and in the absence of any influence of temperature during short-term incubation, we have demonstrated that $\mathrm{Cu}$ tolerance measurements can be performed at a fixed intermediate temperature without interfering with the interpretation of results. Nevertheless and despite the lack of significant statistical difference between incubation temperatures in our experimental conditions ( $\mathrm{p}<0.05$ ) it is interesting to note that, whatever the growth temperature (i.e. $18{ }^{\circ} \mathrm{C}$ and $28{ }^{\circ} \mathrm{C}$ ) and the $\mathrm{Cu}$ treatment (i.e. Control and $\mathrm{Cu}$ ), mean EC50 values were always lower at higher incubation temperature during short-term toxicity tests (i.e. $23^{\circ} \mathrm{C}$ vs $18{ }^{\circ} \mathrm{C}$ and $28{ }^{\circ} \mathrm{C}$ 
vs $23{ }^{\circ} \mathrm{C}$ ). This observed trend may suggest an increase in the sensitivity of phototrophic communities to acute toxicity of copper in response to temperature increase during short-term toxicity tests. Keeping in mind that in the field, the winter-summer temperature swing can exceed $10{ }^{\circ} \mathrm{C}$ (e.g. Pesce et al., 2008; Pesce et al., 2010), it will be necessary to further test the influence of incubation temperature for greater differences in growth temperature (i.e. difference between growth and incubation temperatures $>5{ }^{\circ} \mathrm{C}$ ). We also note that intra-daily temperature variations may be an important factor to consider in studies assessing the combined effects of temperature and toxicants: on the downstream reach of the Morcille river; the difference between minimum and maximum daily water temperature can reach $6{ }^{\circ} \mathrm{C}$ on sunny summer days (unpublished data), and comparable orders of magnitude have been observed in other rivers in Slovakia (Pekárová et al., 2011) and in Montana (Gammons et al., 2005).

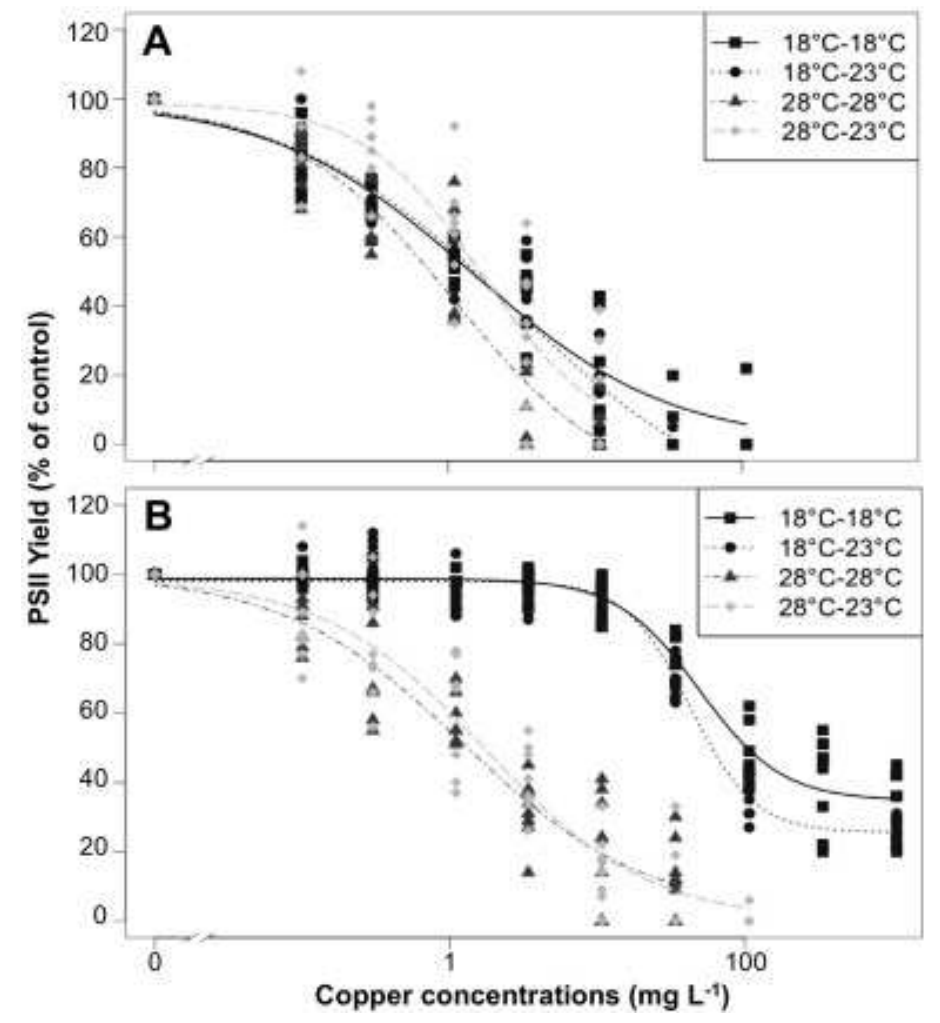

Fig. 4.

Dose-response curves showing inhibition of PSII yield with increasing concentrations of copper for control (A) and Cu-exposed communities (B). For each treatment, first and second temperatures in the legend are growth temperature and shortterm toxicity temperature, respectively. For clarity, data from the three replicate bioassays were pooled to produce a single dose-response curve per treatment.

\section{Conclusions}

5.

Assessing the ecological effects of pollutants is an important aspect of regulations dealing with the sustainable management of water resources. In this context, scientists and regulators face the challenge of going beyond the estimation of pollutant concentrations to take into account the ecotoxicological effects on exposed aquatic communities. Among microbial ecotoxicological approaches, the pollution induced community tolerance (PICT) concept has been proven to be a powerful metric to better link the assessment of ecological and chemical status of ecosystems (Pesce et al., 2016; Tlili et al., 2016). However, prior its implementation in regulatory frameworks as a suitable biomonitoring tool, further work is required to standardize PICT measurement and define baseline tolerance levels at large geographical scales. The present results obtained by testing an extreme environmental scenario (in terms of temperature increase and $\mathrm{Cu}$ exposure) evidenced the potential influence of temperature on both the basal capacity of phototrophic periphyton to tolerate subsequent exposure to $\mathrm{Cu}$ (i.e. influence on tolerance baseline), and its capacity to acquire tolerance after chronic exposure to $\mathrm{Cu}$ (i.e. influence on PICT selection). They reveal that temperature should be an important factor to consider when using PICT at a large geographical or temporal scale, especially for integrating PICT within regulatory 
frameworks to assess ecological and chemical status of aquatic ecosystems. Accordingly, it would be relevant to develop strategies for modeling the influence of temperature on PICT approaches (using $\mathrm{Cu}$ as model compound) to make measurements comparable in space and time by considering robust reference conditions defined at a larger scale (Coulaud et al., 2011).

\section{Acknowledgments}

The authors thank ATT for English-language editing. We also thank Bernard Motte and Bernadette Volat (EMHA, Irstea) for technical support, and the staff at the Aquatic Chemistry Laboratory (LAMA, Irstea) for water chemistry analysis. This project is part of LTER-funded research program "Zone Atelier du Bassin du Rhône" (ZABR).

\section{References}

Adams MS, Dillon CT, Vogt S, Lai B, Stauber JL, Jolley DF (2016) Copper Uptake, Intracellular Localization, and Speciation in Marine Microalgae Measured by Synchrotron Radiation X-ray Fluorescence and Absorption Microspectroscopy. Environ Sci Technol 50: 8827-8839

Barranguet C, Plans M, van der Grinten E, Sinke JJ, Admiraal W (2002) Development of photosynthetic biofilms affected by dissolved and sorbed copper in a eutrophic river. Environ Toxicol Chem 21: 1955-1965

Barranguet C, van den Ende FP, Rutgers M, Breure AM, Greijdanus M, Sinke JJ, Admiraal W (2003) Copper-induced modifications of the trophic relations in riverine algal-bacterial biofilms. Environ Toxicol Chem 22: 1340-1349

Baulch HM, Schindler DW, Turner MA, Findlay DL, Paterson MJ, Vinebrooke RD (2005) Effects of warming on benthic communities in a boreal lake: implications of climate change. Limnol Oceanogr 50: 1377-1392

Barón M, Arellano JB, Gorgé JL (1995) Copper and photosystem II: a controversial relationship. Physiol Plantarum 94: 174-180

Bérard A, Pelte T, Druart JC (1999) Seasonal variations in the sensitivity of Lake Geneva phytoplankton community structure to atrazine. Arch Hydrobiol 145: 277-295

Blanck H (2002) A critical review of procedures and approaches used for assessing pollution-induced community tolerance (PICT) in biotic communities. Hum Ecol Risk Assess 8: 1003-1034

Boivin MEY, Massieux B, Breure AM, van den Ende FP, Greve GD, Rutgers M, Admiraal W (2005): Effects of copper and temperature on aquatic bacterial communities. Aquat Toxicol 71: 345-356

Cantonati M, Angeli N, Virtanen L, Wojtal AZ, Gabrieli J, Falasco E, Lavoie I, Morin S, Marchetto A, Fortin C, Smirnova S (2014) Achnanthidium minutissimum (Bacillariophyta) valve deformities as indicators of metal enrichment in diverse widely-distributed freshwater habitats. Sci Total Environ 475: $201-215$

Cid A, Herrero C, Torres E, Abalde J (1995) Copper toxicity on the marine microlaga Phaeodactylum tricornutum: Effects on photosynthesis and related parameters. Aquat Toxicol 31: 165-174Coulaud R, Geffard O, Xuereb B, Lacaze E, Quéau H, Garric J, Charles S, Chaumot A (2011). In situ feeding assay with Gammarus fossarum (Crustacea): modelling the influence of confounding factors to improve water quality biomonitoring. Water Res 45: 6417-6429 
De Nicola DM 1996. Periphyton responses to temperature at different ecological levels. Algal Ecology: Freshwater Benthic Ecosystems. Academic Press, San Diego, pp. 149e181.

Di Pippo F, Ellwood NTW, Guzzon A, Siliato L, Micheletti E, DePhilippis R, Albertano PB (2012).Effect of light and temperature on biomass, photosynthesis and capsular polysaccharides in cultured phototrophic biofilms. J Appl Phycol 24: 211-220Dorigo U, Bérard A, Rimet F, Bouchez A, Montuelle B (2010) In situ assessment of periphyton recovery in a river contaminated by pesticides. Aquat Toxicol 98: 396-406

Easterling DR, Meehl GA, Parmesan C, Changnon SA, Karl TR, Mearns LO (2000) Climate extremes: observations, modeling, and impacts. Science 289: 2068-2074

Fechner LC, Gourlay-France C, Uher E, Tusseau-Vuillemin MH (2010) Adapting an enzymatic toxicity test to allow comparative evaluation of natural freshwater biofilms' tolerance to metals. Ecotoxicology 19: 1302-1311

Foulquier A, Morin S, Dabrin A, Margoum C, Mazzella N, Pesce S (2015) Effects of mixtures of dissolved and particulate contaminants on phototrophic biofilms: new insights from a PICT approach combining toxicity tests with passive samplers and model substances. Environ Sci Pollut Res 22: 4025-4036

Gammons CH, Nimick DA, Parker SR, Cleasby TE, McCleskey RB (2005) Diel behavior of iron and other heavy metals in a mountain stream with acidic to neutral pH: Fisher Creek, Montana, USA. Geochimica et Cosmochimica Acta, 69: 2505-2516

Guasch H, Admiraal W, Sabater S (2003) Contrasting effects of organic and inorganic toxicants on freshwater periphyton. Aquat Toxicol 64: 165-175

Guasch H, Ivorra N, Lehmann V, Paulsson M, Real M, Sabater S (1998) Community composition and sensitivity of periphyton to atrazine in flowing waters: the role of environmental factors. J Appl Phycol 10: 203-213

Guasch H, Sabater S (1998) Light history influences the sensitivity to atrazine in periphytic algae. J Phycol 34: 233-241

Gustavson K, Wängberg SÅ (1995) Tolerance induction and succession in microalgae communities exposed to copper and atrazine. Aquat Toxicol 32: 283-302

Hirst H, Jüttner I, Ormerod SJ (2002) Comparing the responses of diatoms and macro-invertebrates to metals in upland streams of Wales and Cornwall. Freshwater Biol 47: 1752-1765

Ladomersky E, Petris MJ (2015). Copper tolerance and virulence in bacteria. Metallomics 7: 957-964

Lambert AS, Dabrin A, Morin S, Gahou J, Foulquier A, Coquery M, Pesce S (2016) Temperature modulates phototrophic periphyton response to chronic copper exposure. Environ Pollut 208: 821829

Lambert AS, Morin S, Artigas J, Volat B, Coquery M, Neyra M, Pesce S (2012) Structural and functional recovery of microbial periphyton after a decrease in copper exposure: Influence of the presence of pristine communities. Aquat Toxicol 109: 118-126

Lambert AS, Pesce S, Foulquier A, Gahou J, Coquery M, Dabrin A (2015): Improved short-term toxicity test protocol to assess metal tolerance in phototrophic periphyton: toward standardization of PICT approaches. Environ Sci Pollut Res 22: 1-9 
Larras F, Lambert AS, Pesce S, Rimet F, Bouchez A, Montuelle B (2013) The effect of temperature and a herbicide mixture on freshwater periphytic algae. Ecotox Environ Saf 98: 162-170

Larras F, Rimet F, Gregorio V, Berard A, Leboulanger C, Montuelle B, Bouchez A (2016) Pollutioninduced community tolerance (PICT) as a tool for monitoring Lake Geneva long-term in situ ecotoxic restoration from herbicide contamination. Environ Sci Pollut Res 23: 4301-4311

Montuelle B, Dorigo U, Berard A, Volat B, Bouchez A, Tlili A, Gouy V, Pesce S (2010): The periphyton as a multimetric bioindicator for assessing the impact of land use on rivers: an overview of the ArdiSres-Morcille experimental watershed (France). Hydrobiol 657: 123-141

Morin S, Bonet B, Corcoll N, Guasch H, Bottin M, Coste M (2015) Cumulative stressors trigger increased vulnerability of diatom communities to additional disturbances. Microb Ecol 70: 585-595

Morin S, Lambert AS, Artigas J, Coquery M, Pesce S (2012): Diatom immigration drives biofilm recovery after chronic copper exposure. Freshwat Biol 57: 1658-1666

Morin S, Lambert AS, Planes Rodriguez E, Dabrin A, Coquery M, Pesce S (2017) Changes in copper toxicity towards diatom communities withexperimental warming. J Haz Mat 334: 223-232

Morin S, Pesce S, Tlili A, Coste M, Montuelle B (2010): Recovery potential of periphytic communities in a river impacted by a vineyard watershed. Ecol Indic 10: 419-426

Necchi O (2004) Photosynthetic responses to temperature in tropical lotic macroalgae. Phycol Res 52: $140-148$

Okamoto OK, Pinto E, Latorre LR, Bechara EJH, Colepicolo P (2001) Antioxidant modulation in response to metal-induced oxidative stress in algal chloroplasts. Arch Environ Contam Toxicol 40: 18-24

Pekárová, P, Miklánek P, Halmová D, Onderka M, Pekár J, Kučárová K, Liová S, Škoda P (2011) Long-term trend and multi-annual variability of water temperature in the pristine Bela River basin (Slovakia). J Hydrol 400: 333-340

Pesce S, Fajon C, Bardot C, Bonnemoy F, Portelli C, Bohatier J (2008) Longitudinal changes in microbial planktonic communities of a French river in relation to pesticide and nutrient inputs. Aquat Toxicol 86: 352-360

Pesce S, Margoum C, Montuelle B (2010) In situ relationships between spatio-temporal variations in diuron concentrations and phototrophic periphyton tolerance in a contaminated river. Wat Res 44: 1941-1949

Pesce S, Margoum C, Foulquier A (2016) Pollution-induced community tolerance for in situ assessment of recovery in river microbial communities following the ban of the herbicide diuron. Agri Eco Environ 221: 79-86

Prasad NM, Drej K, Skawinska A, Stratka K (1998) Toxicity of cadmiun and copper in Chlamydomonas reinhardtii wild-type (wt 2137) and cell wall deficient mutant strain (cw 15). Bull Environ Contam Toxicol 60: 306-311

Rijstenbil JW, Derksen JWM, Gerringa LJA, Poortvliet TCW, Sandee A, Van den Berg M, Van Drie J, Wijnholds JA (1994) Oxidative stress induced by copper: defense and damage in the marine planktonic diatom Ditylum brightwellii (Grunow) West, grown in continuous cultures with high and low zinc levels. Mar Biol 119: 583-590

Ritz C, Streibig JC (2005): Bioassay analysis using R. J Stat Softw 12: 1-22 
R Development Core Team (2012) R: a language and environment for statistical computing. R Foundation for Statistical Computing: Vienna. http://www.R-project.org

Rotter S, Sans-Piché F, Streck G, Altenburger R, Schmitt-Jansen M (2011) Active bio-monitoring of contamination in aquatic systems - an in situ translocation experiment applying the PICT concept. Aquat Toxicol 101: 228-236

Sabater S, Guasch H, Ricart M, Romani A, Vidal G, Klunder C, Schmitt-Jansen M (2007): Monitoring the effect of chemicals on biological communities. The periphyton as an interface. Anal Bioanal Chem 387: 1425-1434

Sabatini SE, Juarez AB, Eppis MR, Bianchi L, Luquet CM, Molina MCR (2009) Oxidative stress and antioxidant defenses in two green microalgae exposed to copper. Ecotox Environ Safe 72: 12001206

Serra A \& Guasch H (2009): Effects of chronic copper exposure on fluvial systems: Linking structural and physiological changes of fluvial biofilms with the in-stream copper retention. Sci Total Environ 407: 5274-5282

Schmitt-Jansen M \& Altenburger R (2008) Community-level microalgal toxicity assessment by multiwavelength-excitation PAM fluorometry. Aquat Toxicol 86: 49-58

Schmitt-Jansen M, Veit U, Dudel G, Altenburger R (2008) An ecological perspective in aquatic ecotoxicology: Approaches and challenges. Basic Appl Ecol 9: 337-345

Schmitt-Jansen M, Bley L-M, Krumbiegel ML, Rotter S (2016): Induced community tolerance of periphyton towards combined salt and toxic stress. Freshwater Biol. 61: 2152-2161

Smith MD (2011) An ecological perspective on extreme climatic events: a synthetic definition and framework to guide future research. J Ecol 99: 656-663

Soldo D, Behra R (2000) Long-term effects of copper on the structure of freshwater periphyton communities and their tolerance to copper, zinc, nickel and silver. Aquat Toxicol 47: 181-189

Tlili A, Bérard A, Blanck H, Bouchez A, Cássio F, Eriksson KM, Morin S, Montuelle B, Navarro E, Pascoal C, Pesce S, Schmitt-Jansen M, Behra R (2016) Pollution-induced community tolerance (PICT) towards an ecologically relevant risk assessment of chemicals in aquatic systems. Freshwat Biol 61:2141-2151

Tlili A, Bérard A, Roulier JL, Volat B \& Montuelle B (2010) $\mathrm{PO}_{4}{ }^{3-}$ dependence of the tolerance of autotrophic and heterotrophic biofilm communities to copper and diuron. Aquat Toxicol 98: 165177

Tlili A, Marechal M, Bérard A, Volat B \& Montuelle B (2011) Enhanced co-tolerance and cosensitivity from long-term metal exposures of heterotrophic and autotrophic components of fluvial biofilms. Sci Total Environ 409: 4335-4343

Tlili A, Montuelle B (2011) Microbial pollution-induced community tolerance. Tolerance to Environmental Contaminants. CRC London: 85-108

Tlili A, Hollender J, Kienle C, Behra R (2017) Micropollutant-induced tolerance of in situ periphyton: Establishing causality in wastewater-impacted streams. Water Research 111: 185-194

Wreford A, Adger WN (2010) Adaptation in Agriculture: Historic Effects of Heat Waves and Droughts on UK Agriculture. Inter J Agric Sustain 8: 278-289 